\title{
Cellular localization of inhibin mRNA in the bovine ovary by in-situ hybridization
}

\author{
A. H. Torney, Y. M. Hodgson, R. Forage* and D. M. de Kretser \\ Department of Anatomy, Monash University, Melbourne, Victoria 3168, Australia; and \\ *Biotechnology Australia Pty Ltd, 28 Barcoo St, East Rosevill, Sydney, New South Wales 2069, \\ Australia
}

\begin{abstract}
Summary. Hybridization histochemistry has been used to detect the presence of mRNA for the $\alpha$ and $\beta_{\mathrm{A}}$ subunit of inhibin in tissue sections of the ovary of cows. ${ }^{32} \mathrm{P}$-labelled cDNAs, complementary to the bovine $\alpha$ or $\beta_{\mathrm{A}}$ subunit of inhibin or to a control segment of plasmid DNA (pBR 322), were used. The $\alpha$ subunit mRNA was located in the granulosa layer of antral follicles $>0.36 \mathrm{~mm}$ in diameter while the $\alpha$ and $\beta_{\mathrm{A}}$ subunit mRNA were both present in follicles of $>0.8 \mathrm{~mm}$. In these latter follicles, the thecal layer hybridized with only the $\alpha$ subunit mRNA. No hybridization of the $\alpha$ or $\beta_{\mathrm{A}}$ subunit probe was found in the cells of the corpus luteum. Hybridization of both probes was abolished when the tissue sections were pretreated with ribonuclease (RNAse). The plasmid cDNA did not hybridize to any of the tissue sections. This study demonstrates that mRNA for the $\alpha$ inhibin subunit can be detected in granulosa and theca cells whereas the $\beta_{\mathrm{A}}$ inhibin subunit mRNA is restricted to the granulosa cells. These results provide evidence for an independent regulation of expression for the two subunits of inhibin.
\end{abstract}

Keywords: inhibin; cattle; follicle; in-situ hybridization; mRNA; ovary

\section{Introduction}

Inhibin is a non-steroidal peptide hormone of gonadal origin that selectively suppresses FSH secretion from the pituitary. Ovarian follicular fluid is a rich source of inhibin which has been used as the starting material for the isolation and purification of inhibin by several groups (Robertson et al., 1985, 1986; Miyamoto et al., 1985; Ling et al., 1985; Rivier et al., 1985; Fukuda et al., 1986). Inhibin has a molecular weight of $M_{\mathrm{r}} 31000$ and is composed of two disulphide-linked polypeptide chains of $M_{\mathrm{r}} 20000$ and $M_{\mathrm{r}} 15000$ termed $\alpha$ and $\beta_{\mathrm{A}}$, respectively. The $M_{\mathrm{r}} 20000$ subunit is a processed form of a larger $M_{\mathrm{r}} 43000$ subunit (Robertson et al., 1985). Cloning of the genes for the inhibin subunits from cattle (Forage et al., 1986) and pig (Mason et al., 1985) granulosa cells has established that the $\alpha$ and $\beta_{\mathrm{A}}$ subunits are both products of different genes.

In-vitro studies have shown that the granulosa cells are the major production site of inhibin in the ovary (Erickson \& Hsueh, 1978; Henderson \& Franchimont, 1981, 1983). Immunohistochemical studies in the rat and human ovary also support these findings (Merchenthaler et al., 1987; Woodruff et al., 1988). Because many of the early studies used pools of granulosa cells or follicular fluid to measure inhibin, rather than samples from individual follicles, they provided no conclusions as to the production of inhibin by specific follicles. However, Tsonis et al. (1983) and Henderson et al. (1984) have examined inhibin activity in sheep follicular fluid from isolated follicles greater than $1.4 \mathrm{~mm}$ in diameter. Both groups showed a positive correlation between follicular diameter and the inhibin content of follicular fluid. In the present study we have used the technique 
of hybridization histochemistry to investigate the cellular distribution of the mRNA for the $\alpha$ and $\beta_{\mathrm{A}}$ subunits of inhibin in the ovary of cows.

\section{Materials and Methods}

Preparation of tissues. Ovaries from 20 cows were obtained from the abattoir and frozen in a hexane/solid $\mathrm{CO}_{2}$ slurry, cut into $1 \mathrm{~cm}^{3}$ blocks, embedded in O.C.T. compound (Tissue Tek, Miles Laboratories, Mulgrave Nth, Victoria 3170 , Australia) and stored at $-70^{\circ} \mathrm{C}$. Before freezing, corpora lutea were dissected from the ovaries, bisected and classified into four groups by the method of Ireland $e t$ al. (1980). Sections of 6-8 $\mu \mathrm{m}$ were cut on a cryostat at $-15^{\circ} \mathrm{C}$, thawed onto gelatin-coated glass slides and immediately cooled to $-78^{\circ} \mathrm{C}$ for 30 min on a block of solid $\mathrm{CO}_{2}$. Sections were then fixed in $4 \%$ glutaraldehyde for $5 \mathrm{~min}$ at room temperature. Prehybridization was carried out for a total of $2 \mathrm{~h}, \mathrm{l}$ h at room temperature and $\mathrm{l} \mathrm{h}$ at $37^{\circ} \mathrm{C}$ in hybridization buffer $(50 \mathrm{~mm}$-phosphate buffer $\mathrm{pH} 7 \cdot 0 ; 0.75 \mathrm{M}-\mathrm{NaCl} ; 0.075 \mathrm{M}$-trisodium citrate; $0.2 \%$ bovine serum albumin; $0.2 \%$ polyvinylpyrrolidione; $0.2 \%$ Ficoll; $0.002 \%$ herring sperm DNA; $0.004 \%$ t-RNA; $50 \%$ formamide). The sections were then rinsed twice in ethanol, airdried and stored over ethanol at $-20^{\circ} \mathrm{C}$ until hybridized. To verify DNA/RNA hybridization, a group of tissue sections was subjected to RNAse treatment $\left(25 \mu \mathrm{g} / \mathrm{ml}\right.$; pancreatic ribonuclease $\mathrm{A}$ at $42^{\circ} \mathrm{C}$ for $1 \mathrm{~h}$; Gee et al., 1983) before hybridization.

cDNA probes. Three cDNA probes were used in this study. The $\alpha$ probe consisted of 729 base pairs encoding the amino acid sequence 1--242 of the $\alpha$ subunit of bovine inhibin. The $\beta_{A}$ probe was 327 base pairs long encoding the region -16 to 92 of the $\beta_{\mathrm{A}}$ subunit (Forage et al., 1986). This probe is homologous to the $\beta_{\mathrm{A}}$ subunit of pig inhibin (Mason et al., 1985). The third probe used as the negative control was 1600 base pairs of bacterial DNA (pBR322). cDNA probes were labelled with ${ }^{32} \mathrm{P}$ according to Feinberg \& Vogelstein (1984) in a total volume of $30 \mu \mathrm{l}$ by adding the following reagents to a microfuge tube; $0-13.6 \mu \mathrm{l}$ distilled water, $6 \mu$ l oligo-labelling buffer solution, $1 \cdot 2 \mu \mathrm{l}$ BSA ( $10 \mathrm{mg} / \mathrm{ml}), 5-19 \mu \mathrm{l}$ cDNA probe $(25 \mathrm{ng}), 3 \mu \mathrm{ldCTP}$ (sp. act. $3000 \mathrm{Ci} / \mathrm{mmol}$ : Amersham, Melbourne, Victoria 3004 , Australia) and $1 \cdot 2 \mu$ DNA polymerase $1(1 \mu \mathrm{U}$ Klenow fragment/ml: Boehringer Mannheim, West St Kilda, Victoria 3[82, Australia). The tubes were incubated overnight at room temperature and the reaction was stopped by adding $70 \mu \mathrm{l} 20 \mathrm{~mm}-\mathrm{Tris}-\mathrm{HCl}, 20 \mathrm{~mm}-\mathrm{NaCl}, 2 \mathrm{~mm}-\mathrm{EDTA}, 0 \cdot 25 \% \mathrm{SDS}, 1 \mathrm{~mm}-\mathrm{dCTP}, \mathrm{pH} 7 \cdot 5$. Labelled cDNA was separated from free $\left[{ }^{32} \mathrm{P}\right] \mathrm{dCTP}$ on a G-100 Sephadex column pre-run with herring sperm DNA to block non-specific binding sites. The labelled cDNA was collected and precipitated at $-20^{\circ} \mathrm{C}$ by adding $1 / 10$ volume of $4 \mathrm{M}-\mathrm{NaCl}$ and 2 volumes of ethanol. Precipitated cDNA was then resuspended in $350 \mu \mathrm{l}$ of hybridization buffer and denatured by boiling for $5 \mathrm{~min}$ and cooled on ice.

Hybridization. Samples $(25 \mu \mathrm{l})$ of $\left[{ }^{32} \mathrm{P}\right] \mathrm{cDNA}$ probe in hybridization buffer were applied to each section and overlaid with a coverslip. The slides were subsequently suspended over hybridization buffer in a sealed plastic tray at $37^{\circ} \mathrm{C}$ for 3 days. The coverslips were removed by rinsing in $2 \times$ SSC (Standard Saline Citrate: $1 \times$ SSC; $0.1 \mathrm{M}-\mathrm{NaCl}$, $0.015 \mathrm{M}$-trisodium citrate) and the sections were then washed in $2 \times \mathrm{SSC}$ for $30 \mathrm{~min}, 1 \times \mathrm{SSC}$ for $15 \mathrm{~min}$ at $37^{\circ} \mathrm{C}$ and $0.5 \times \mathrm{SSC}$ for $30 \mathrm{~min}$ at $37^{\circ} \mathrm{C}$. Slides were washed twice in ethanol, dried, and placed under Ilford XAR X-ray film overnight before dipping in Ilford G-5 nuclear emulsion (1:1, v/v, with distilled water) and exposed for 2-4 weeks at $4^{\circ} \mathrm{C}$. The slides were developed and viewed on a Leitz Orthoplan (Ernst Leitz Wetzlar GmbH, Hawthorn East, Victoria 3142, Australia) microscope under bright- and dark-field condensers.

Measurement of follicular size. Follicular diameters were measured on tissue sections using a Leitz ASM Image Analysis system (Ernst Wetzlar $\mathrm{GmbH}$ ) attached to a Leitz Orthoplan microscope. Each diameter was calculated, assuming the follicle to be spherical, from the traced circumference of the cross-sectional basement membrance profile follicle from a group of serial sections. The coefficient of variation for repeated measurements of the estimated diameter for a given follicle was $0.76 \%(n=10)$.

\section{Results}

Hybridization of the $\alpha$ probe occurred over the granulosa and thecal cells while the $\beta_{\mathrm{A}}$ probe was localized in the granulosa cells only; neither probe hybridized to the stromal tissue. This localization was considered specific because the sections did not hybridize with the control plasmid DNA (pBR 322). Furthermore, hybridization did not occur in those sections pretreated with RNAse $(25 \mu \mathrm{g} / \mathrm{ml})$.

A relationship was established between $\alpha$ and $\beta_{\mathrm{A}}$ subunit probe hybridization and follicular diameter in the 31 follicles examined (Table 1). Small antral and preantral follicles ranging between 0.04 and $0.21 \mathrm{~mm}$ in diameter showed no hybridization with probes for either subunit of inhibin 
(Figs la \& $1 \mathrm{~b}$ ). In follicles ranging from 0.36 to $0.75 \mathrm{~mm}$ in diameter, hybridization of the $\alpha$ subunit probe was observed only in the granulosa cells (Figs $2 \mathrm{a} \& 2 \mathrm{~b}$ ). Hybridization of the $\beta_{\mathrm{A}}$ subunit probe was not observed in any of these follicles. Of 13 larger follicles $(0.80-3.00 \mathrm{~mm})$ examined, the $\alpha$ subunit probe was localized in the granulosa cells in 11 (Table 1 ; Figs $3 a$ \& 3b), while in 10 a signal was produced over the thecal layer (Figs $4 a, b$, e \& f). Hybridization of the $\beta_{\mathrm{A}}$ subunit probe was observed over the granulosa cells in 8 of these 13 follicles (Figs $3 \mathrm{c} \& 3 \mathrm{~d}$ ). In some follicles the intensity of hybridization appeared to be greater in the periantral granulosa cells (Figs 4c \& 4d), and in 4 of the follicles it was difficult to establish any localization of the $\beta_{\mathrm{A}}$ probe due to the high background. The $\beta_{\mathrm{A}}$ subunit probe did not hybridize the thecal layer in any of the follicles examined. In the two largest follicles (15.0 and $20.0 \mathrm{~mm}$ in diameter) a strong autoradiographic signal was seen over the granulosa layer with the $\alpha$ and $\beta_{\mathrm{A}}$ probes (Figs $5 \mathrm{a} \& 5 \mathrm{~b} ; 5 \mathrm{c} \& 5 \mathrm{~d}$ ). Tissue sections of corpora lutea from the four functional classes described by Ireland et al. (1980), which are classified according to time after ovulation, failed to hybridize with any of the probes (Figs 6a \& 6b).

Table 1. Distribution pattern of hybridization of inhibin $\alpha$ and $\beta_{\mathrm{A}}$ subunit $\mathrm{cDNA}$ in follicles of cows

\begin{tabular}{|c|c|c|c|c|}
\hline \multirow{2}{*}{$\begin{array}{l}\text { Follicle } \\
\text { diam. } \\
(\mathrm{mm})\end{array}$} & \multicolumn{2}{|c|}{$\alpha$ Subunit probe } & \multicolumn{2}{|c|}{$\beta_{\mathrm{A}}$ Subunit probe } \\
\hline & Granulosa & Theca & Granulosa & Theca \\
\hline 0.04 & - & - & - & - \\
\hline 0.04 & - & - & - & - \\
\hline $0 \cdot 05$ & - & - & - & - \\
\hline 0.09 & - & - & - & - \\
\hline $0 \cdot 12$ & - & - & - & - \\
\hline $0 \cdot 15$ & - & - & - & - \\
\hline $0 \cdot 15$ & - & - & - & - \\
\hline $0 \cdot 21$ & - & - & - & - \\
\hline $0 \cdot 36$ & ++ & - & - & - \\
\hline 0.42 & ++ & - & - & - \\
\hline 0.50 & ++ & - & - & - \\
\hline $0 \cdot 60$ & ++ & - & - & - \\
\hline 0.75 & ++ & - & - & - \\
\hline 0.75 & ++ & - & $-\mathbf{a}$ & $-\mathbf{a}$ \\
\hline 0.80 & $+t+$ & ++ & ++ & - \\
\hline 0.80 & ++ & ++ & ++ & - \\
\hline 1.00 & +++ & - & ++ & - \\
\hline $1 \cdot 10$ & +++ & ++ & ++ & - \\
\hline $1 \cdot 20$ & - & $++t$ & $-\mathbf{a}$ & $-\mathbf{a}$ \\
\hline $1 \cdot 25$ & +++ & - & ++ & - \\
\hline $1 \cdot 30$ & ++ & +++ & + & - \\
\hline $1 \cdot 50$ & ++ & $+t$ & ++ & - \\
\hline $1 \cdot 50$ & ++ & - & $-\mathbf{a}$ & $-a$ \\
\hline $2 \cdot 10$ & + & ++ & ++ & - \\
\hline $2 \cdot 10$ & ++ & +++ & $-\mathbf{a}$ & $-\mathbf{a}$ \\
\hline $2 \cdot 50$ & + & ++ & - & - \\
\hline 3.00 & - & ++ & - & - \\
\hline $15 \cdot 0$ & +++ & - & +++ & - \\
\hline $20 \cdot 0$ & +++ & - & +++ & - \\
\hline
\end{tabular}

+++ , Localization of probes obvious without dark-field microscopy; ++ , dark-field microscopy required to verify localization; + , localization only distinguishable with darkfield microscopy; -, no localization of cDNA; -a, localization of the probe undecided due to high background. 

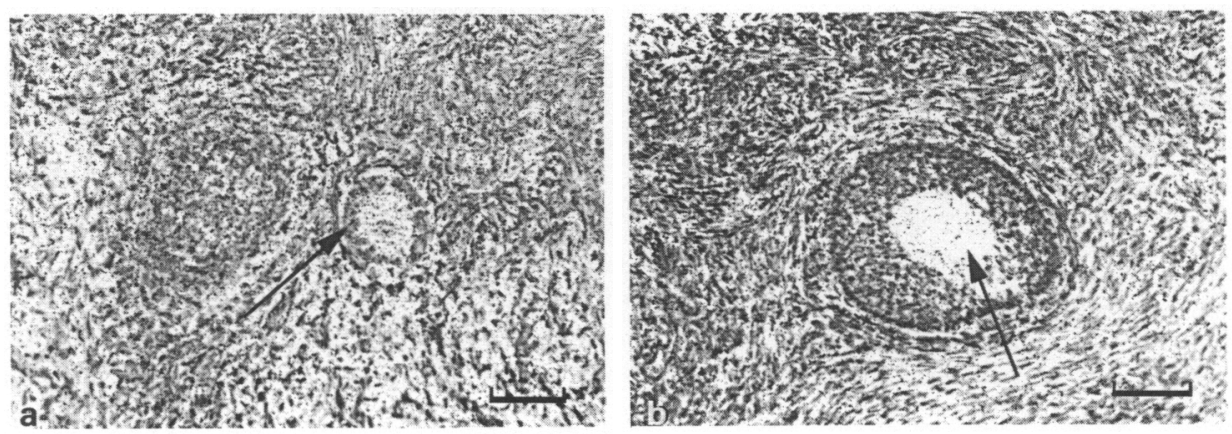

Fig. 1. Small diameter follicles showing no hybridization of either probe ('-' in Table 1). (a) A $0.04 \mathrm{~mm}$ diameter preantral follicle with oocyte surrounded by a single layer of granulosa cells (arrow). Bar $=0.09 \mathrm{~mm}$. (b) A $0.21 \mathrm{~mm}$ diameter follicle with developing antrum (arrow). Bar $=0.07 \mathrm{~mm}$.
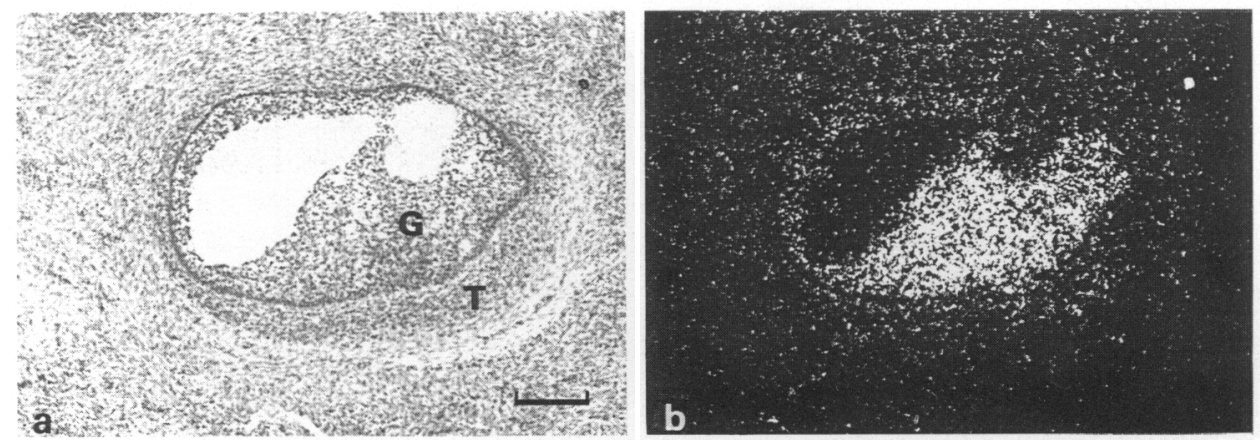

Fig. 2. A $0.75 \mathrm{~mm}$ antral follicle demonstrating hybridization of the $\alpha$ subunit probe in the granulosa $(G)$ layer only (a, bright-field; $b$, dark-field). Thecal layer $(T)$. Bar $=0.18 \mathrm{~mm}$.

\section{Discussion}

The cytological localization of mRNA for the $\alpha$ and $\beta_{\mathrm{A}}$ subunits of inhibin in ovarian follicles of cows supports the results of previous studies which have identified the granulosa cell as the site of inhibin production (Erickson \& Hsueh, 1978; Henderson \& Franchimont, 1981; Channing et al., 1982). This study also provides evidence for independent regulation of inhibin subunit production by demonstrating $\alpha$ subunit mRNA expression in a wider population of cells than the $\beta_{\mathrm{A}}$ subunit. The increased levels of mRNA for the $\alpha$ and $\beta_{A}$ subunits, as shown by the intensity of silver grains, with increasing follicular diameter confirms previous correlations between inhibin content and follicular diameter (sheep: Tsonis et al., 1983; cow: Henderson et al., 1984). This study also demonstrates that very small antral and preantral follicles $(<1.4 \mathrm{~mm})$ contain mRNA for the inhibin subunits. Follicles of such a size have not previously been examined, the inhibin content of follicular fluid measured by Tsonis et al. (1983) and Henderson et al. (1984) being taken from follicles $1.4-6.0 \mathrm{~mm}$ and $2.0 \mathrm{~mm}$ in diameter, respectively. The presence of mRNA for the inhibin subunits suggests, but does not prove, that follicles of this size are capable of secreting inhibin. However, the recent in-vivo studies by Findlay et al. (1986) in the sheep, which showed a decline in inhibin secretion following electro-cauterization of all visible follicles greater than $0.5 \mathrm{~mm}$ in diameter, support the view that $\mathrm{mRNA}$ for both inhibin subunits in follicles $>0.8 \mathrm{~mm}$ in diameter reported herein may be equated with inhibin production. 

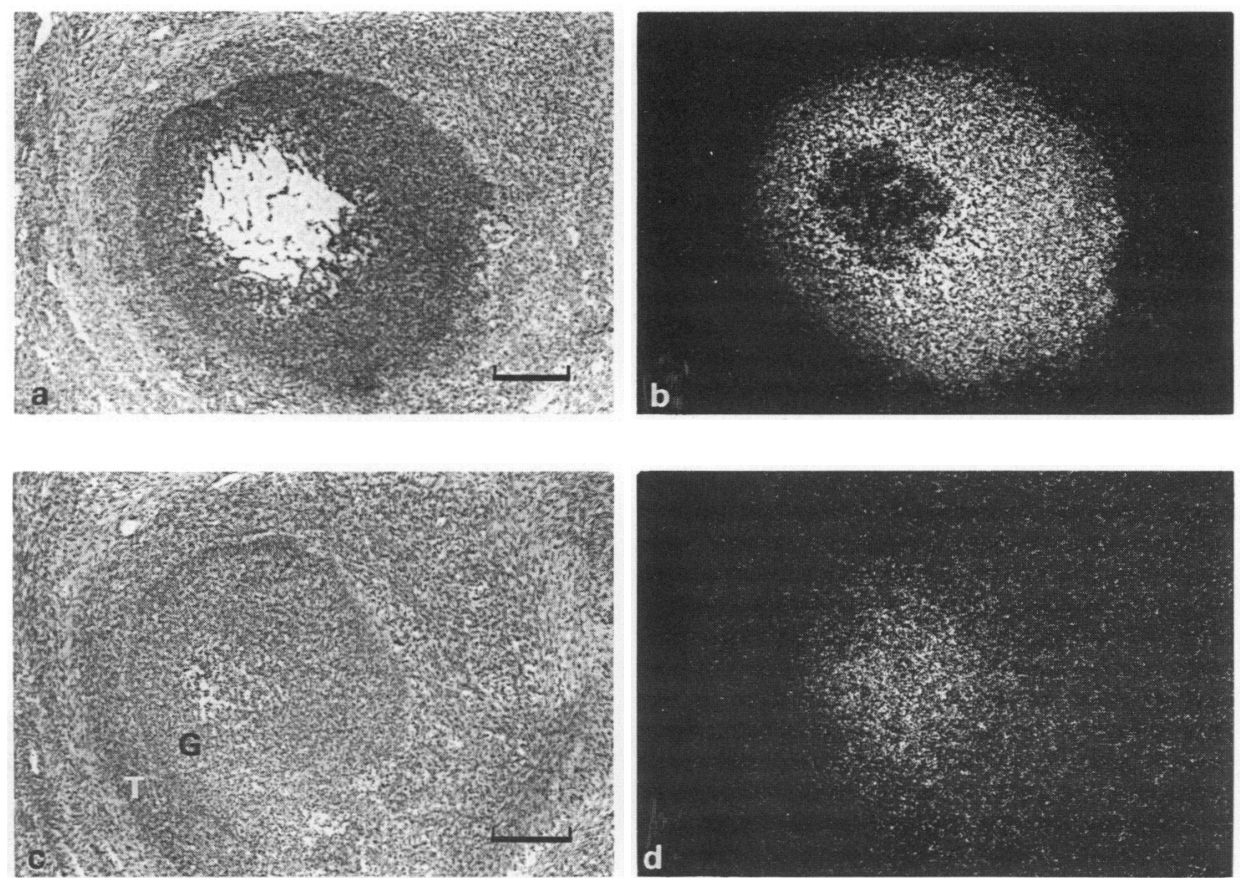

Fig. 3. Serial sections of a $1.25 \mathrm{~mm}$ follicle illustrating hybridization of the $\alpha$ and $\beta_{\mathrm{A}}$ subunit probe over the granulosa layer $(G)$ only. Theca layer $(T)$. (a \& b, bright-field and dark-field with the $\alpha$ probe; $\mathrm{c} \& \mathrm{~d}$, bright-field and dark-field using probe $\left.\beta_{\mathrm{A}}\right) . B a r=0.19 \mathrm{~mm}$.

Several of the larger follicles examined $(1 \cdot 0-3 \cdot 0 \mathrm{~mm})$ failed to localize the $\alpha$ probe in the granulosa and thecal cells or the $\beta_{\mathrm{A}}$ probe in the granulosa cells. Tsonis et al. (1983) reported that the inhibin content in follicles could vary significantly and suggested that this variability may be due to atresia of some of the follicles. Regrettably, no assessment of atresia was possible in the preparations used for in-situ hybridization since the need for frozen sections resulted in relatively poor quality preparations. These were unsuitable for histological assessment of atresia according to the criteria of Hay et al. (1976) and Moor et al. (1978). In a large proportion of follicles expressing the $\alpha$ subunit for inhibin, no mRNA for the $\beta_{\mathrm{A}}$ subunit could be detected. The more widespread distribution of $\alpha$ subunit mRNA supports the biochemical observations of Mason et al. (1985) who noted a 10-fold excess of pig ovarian mRNA for the $\alpha$ subunit in comparison with that for the $\beta_{\mathrm{A}}$ subunit. A separate dot blot study in cattle ovaries (R. G. Forage, unpublished data) using $\alpha$ and $\beta_{\mathrm{A}}$ subunit probes of similar length (410 and $450 \mathrm{bp}$, respectively) and specific activities $\left(1-2 \times 10^{6}\right.$ c.p.m. $/ \mu \mathrm{g}$ ) has confirmed the differential ratio between the $\alpha$ and $\beta_{\mathrm{A}} \mathrm{mRNA}$. Studies by Bicsak et al. (1988) have demonstrated high levels of free $\alpha$ inhibin subunit, but not $\beta_{\mathrm{A}}$ subunit, in conditioned media from rat granulosa cells and in granulosa cell extracts. Our observations in cattle ovarian follicles in situ suggest that expression of the $\beta_{\mathrm{A}}$ subunit may be the rate-limiting step in the formation of the inhibin dimer. It is clear that studies of the regulation of the expression of the $\alpha$ and $\beta_{\mathrm{A}}$ subunits will be crucial in understanding the secretory capacity of follicles for inhibin.

The increased intensity of the hybridization of cDNA probes over the antral granulosa cells in some follicles suggests the existence of subpopulations of granulosa cells within a given follicle. Recent immunolocalization of another follicular protein, follicle regulatory protein (FRP), has also demonstrated a heterogeneous distribution of staining within the granulosa cell layer (Fujimori et al., 1988). The concept of granulosa cell subpopulations is not novel. Mural granulosa cells of rat follicles contain more LH/hCG receptors (Amsterdam et al., 1975; Midgely, 1979) and are more active in steroid production (Golding et al., 1986; Zlotkin et al., 1986). Conversely, prolactin 

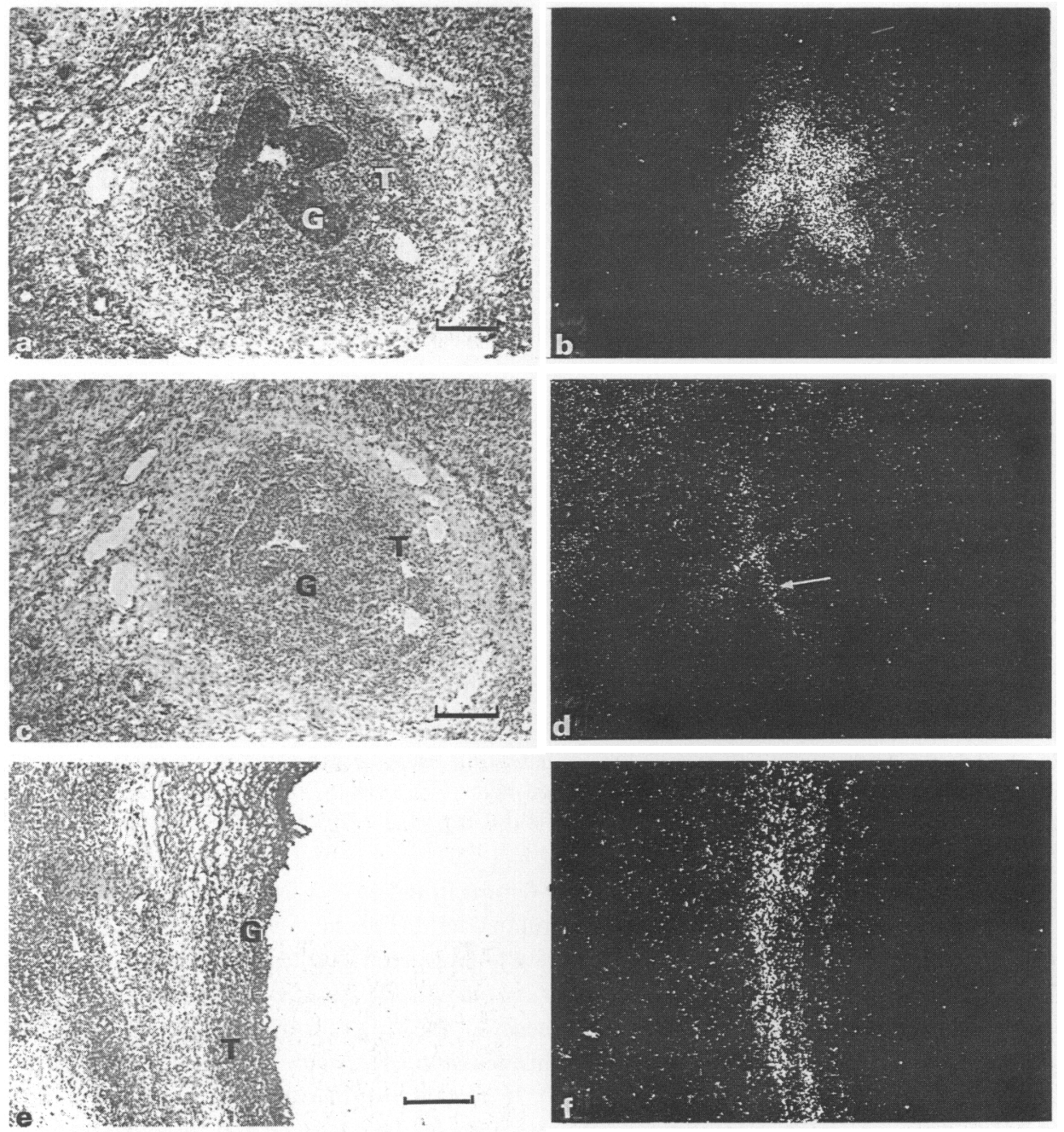

Fig. 4. A $0.8 \mathrm{~mm}$ follicle demonstrating hybridization of the $\alpha$ probe to the granulosa layer $(\mathrm{G})$ and thecal layer (T) ( $a$, bright-field; b, dark-field); a serial section showing hybridization of the $\beta_{\mathrm{A}}$ probe by the periantral granulosa cells (c, bright-field; $d$, dark-field: bar $=0.17 \mathrm{~mm}$ ) and a $2.5-\mathrm{mm}$ follicle illustrating hybridization of the $\alpha$ probe to the thecal layer (e, bright-field; $\mathrm{d}$, dark-field; bar $=0 \cdot 2 \mathrm{~mm}$ ).

receptors are more abundant (Dunaif et al., 1982) and the incorporation of $\left[{ }^{3} \mathrm{H}\right]$ thymidine is greater in antral granulosa cells (Hirshfield, 1986). The preferential localization of the inhibin mRNA in antral granulosa cells and its high concentration in follicular fluid indicates that this protein may contribute to the microenvironment of the follicle. The regulation of inhibin production by factors known to stimulate granulosa cell differentiation (Bicsak et al., 1986) supports a role for inhibin in intrafollicular granulosa cell differentiation. Further in-situ studies are required, however, to determine the regulation of inhibin subunit expression by these factors in individual follicles.

Synthesis of inhibin by the corpus luteum is implied by the demonstration that serum inhibin concentrations are elevated in the luteal phase of the human menstrual cycle (McLachlan et al., 1987) and, when combined with the detection of the inhibin $\alpha$ subunit mRNA in rat and human luteal cells (Davis et al., 1986, 1987; Tsonis et al., 1987), supports the view that the luteal cells are a source of inhibin. This view is further supported by the detection of inhibin in rat luteal cells by 

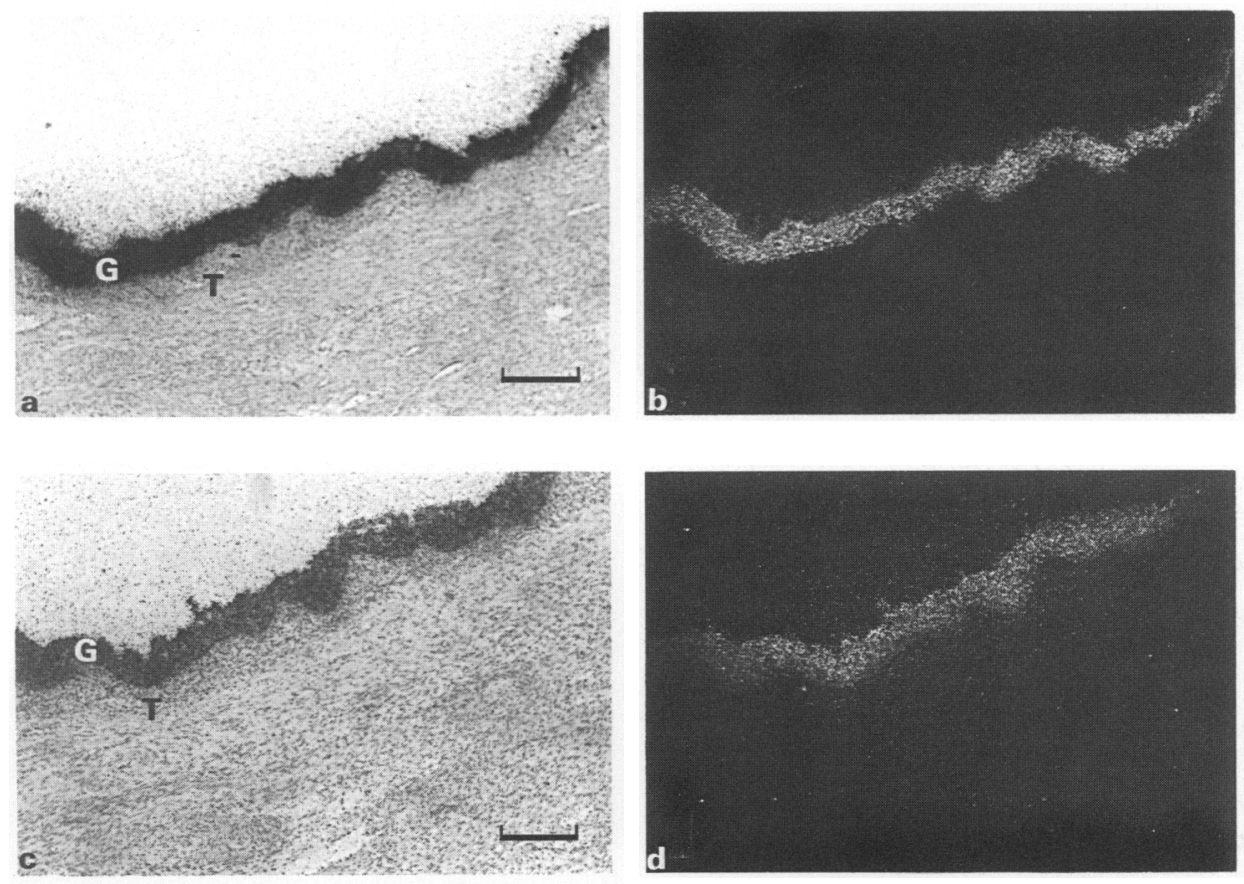

Fig. 5. A large $20.00 \mathrm{~mm}$ diameter follicle demonstrating hybridization of the $\alpha$ and $\beta_{\mathrm{A}}$ subunit probes over the granulosa layer $(G)$. No hybridization occurred over the thecal layer $(T)$. (a \& $\mathrm{b}$, bright-field and dark-field of section hybridized with the $\alpha$ probe; $c \& d$, bright-field and dark-field of section hybridized with the $\beta_{\mathrm{A}}$ probe). $\mathrm{Bar}=0.61 \mathrm{~mm}$.
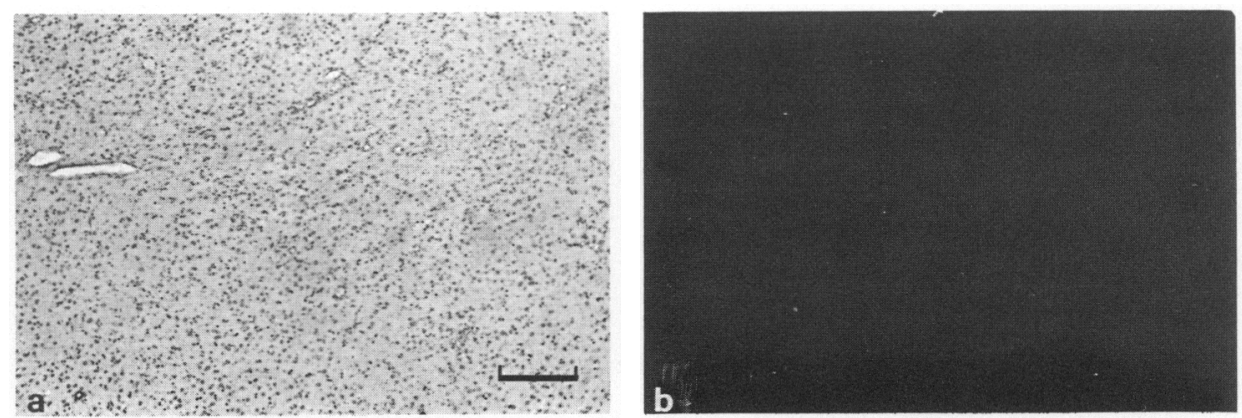

Fig. 6. Absence of mRNA for the $\alpha$ subunit in a section of corpus luteum, class I. (a, brightfield; $b$, dark-field). Bar $=0.57 \mathrm{~mm}$.

immunocytochemistry using an antiserum to a synthetic fragment of the pig inhibin $\alpha$ subunit (Cuevas et al., 1987; Merchenthaler et al., 1987). In-situ hybridization studies in the rat during the oestrous cycle, however, have failed to demonstrate any localization of inhibin subunit mRNA in luteal cells (Woodruff et al., 1988). Moreover, studies by Henderson \& Franchimont (1983) and Hasegawa et al. (1988) of the bovine corpus luteum, unlike those of the rat and human, failed to detect inhibin by radioimmunoassay or bioassay. These results are supported by those of Rodgers et al. (1989) who failed to detect mRNA for the $\alpha$ and $\beta_{\mathrm{A}}$ subunits of inhibin in the corpora lutea of cattle and sheep. The results of the present study are confirmatory in showing no hybridization of cDNA probes for either inhibin subunit in the bovine corpus luteum. These results suggest that the production of inhibin by the corpus luteum may be species specific. 
We thank Miss A. Martsi for technical assistance and Mrs Judy Stirling for typing the manuscript. This work was supported in part by the NH \& MRC of Australia and by a grant from Biotechnology Australia Pty Ltd.

\section{References}

Amsterdam, A., Koch, Y., Lieberman, M.E. \& Linder, H.R. (1975) Distribution of binding sites for human chorionic gonadotrophin in the preovulatory follicle of the rat. J. Cell Biol. 67, 894-900.

Bicsak, T.A., Tucker, E.M., Cappel, S., Vaughan, J., Rivier, J., Vale, W. \& Hsueh, A.J.W. (1986) Hormonal regulation of granulosa cell inhibin biosynthesis. Endocrinology 119, 2711-2719.

Bicsak, T.A., Ceijander, S.B., Vale, W. \& Hsueh, A.J.W. (1988) Inhibin: studies of stored and secreted forms by biosynthetic labelling and immunodetection in cultured rat granulosa cells. Endocrinology 122, 741-748.

Channing, C.P., Anderson, L.D., Hoover, D.J., Kolena, J., Oskeen, K.G., Pomerantz, S.H. \& Tanabe, K. (1982) The role of nonsteroidal regulation of cortisol in oocyte and follicular maturation. Recent Prog. Horm. Res. 38, 331-400.

Cuevas, P., Ying, S.Y., Ling, N., Ueno, N., Esch, F. \& Guillemin, R. (1987)Immunohistochemical detection of inhibin in the gonad. Biochem. Biophys. Res. Commun. 142, 23-30.

Davis, S.R., Dench, F., Nikolaidis, I., Clements, J.A., Forage, R.G., Krozowski, Z. \& Burger, H.G. (1986) Inhibin A-subunit gene expression in the ovaries of immature female rats is stimulated by pregnant mare serum gonadotrophin. Biochem. Biophys. Res. Commun. 138, 1191-1202.

Davis, S.R., Krozowski, Z., Mclachlan, R.I. \& Burger, H.G. (1987) Inhibin gene expression in the human corpus luteum. J. Endocr. 115, R21-R23.

Dunaif, A.E., Zimmerman, E.A., Friesen, H.G. \& Frantz, A.G. (1982) Intracellular localization of prolactin receptor and prolactin in the rat ovary by immunocytochemistry. Endocrinology 110, 1465-1471.

Erickson, G.F. \& Hsueh, A.J.W. (1978) Secretion of inhibin by rat granulosa cells in vitro. Endocrinology 103, 1960-1963.

Feinberg, A.P. \& Vogelstein, B. (1984) A technique for radiolabelling DNA restriction endonuclease fragments to high specific activity. Addendum. Analyt. Biochem. 137, 266-267.

Findlay, J.K., Tsonis, C.G., Staples, L.O. \& Cahill, R.N.P. (1986) Inhibin secretion by the sheep ovary. J. Reprod. Fert. 76, 751-761.

Forage, R.G., Ring, J.M., Brown, R.W., McInerney, B.V., Corbon, G.S., Gregson, R.P., Robertson, D.M., Morgan, F.J., Hearn, M.T.W., Findlay, J.K., Wettenhall, R.E.H., Burger, H.G. \& de Kretser, D.M. (1986) Cloning and sequence analysis of cDNA species coding for the two subunits of inhibin from bovine follicular fluid. Proc. natn. Acad. Sci. USA 83, 309I-3095.

Fujimori, K., Rodgers, K.E., Nakamura, R.M., Katt, E., Yanagihara, D.L. \& di Zerega, G.S. (1988) Localization of follicle regulatory protein in the porcine ovary. J. Histochem. Cytochem. 36, 589-595.
Fukuda, M., Miyamoto, K., Hasegawa, Y., Nomura, M., Igarashi, M., Kangawa, K. \& Matsuo, H. (1986) Isolation of bovine follicular fluid inhibin of about $32 \mathrm{kDa}$. Molec. cell. Endocr. 44, 55-60.

Gee, C.E., Chen, C.L.C. \& Roberts, J.L. (1983) Identification of proopiomelanocortin neurons in rat hypothalamus by in situ cDNA-mRNA hybridization. Nature, Lond. 306, 374376.

Golding, N.B., Farkash, Y., Goldschmit, D. \& Orly, J. (1986) Immunofluorescent probing of the mitochondrial cholesterol side-chain cleavage cytochrome P450 expressed in differentiating granulosa cells in culture. Endocrinology 119, 2821-2832.

Hasegawa, Y., Miyamoto, K., Igarashi, M., Yankaka, T., Sasaki, K. \& Iwamura, S. (1988) Changes in serum concentrations of inhibin during the estrous cycle of the rat, pig and cow. In Inhibin-Non-Steroidal Regulation of Follicle Stimulating Hormone Secretion, pp. 119-133 Eds. H. G. Burger, D. M. de Kretser, J. K. Findlay \& M. Igarashi. Raven Press, New York.

Hay, M.F., Cran, D.G. \& Moor, R.M. (1976) Structural changes occurring during atresia in sheep ovarian follicles. Cell. Tiss. Res. 169, 515-529.

Henderson, K.M. \& Franchimont, P. (1981) Regulation of inhibin production by bovine ovarian cells in vitro. J. Reprod. Fert. 63, 431-442.

Henderson, K.M. \& Franchimont, P. (1983) Inhibin production by bovine tissues in vitro and its regulation by androgens. J. Reprod. Fert. 67, 291-298.

Henderson, K.M., Franchimont, P., Charlet-Renard, Ch. \& McNatty, K.P. (1984) Effects of follicular atresia on inhibin production by bovine granulosa cells in vitro and inhibin concentrations in the follicular fluid. J. Endocr. 72, 1-8.

Hirshfield, A.N. (1986) Patterns of $\left[{ }^{3} \mathrm{H}\right]$ thymidine incorporation differ in immature rats and mature cycling rats. Biol. Reprod. 34, 229-235.

Ireland, J.J., Murphee, R.L. \& Coulson, P. (1980) Accuracy of predicting stages of bovine estrous cycle by gross appearance of the corpus luteum. J. Dairy. Sci. $63,155-160$.

Ling, N., Ying, S.Y., Ueno, N., Esch, F., Deoroy, L. \& Guillemin, R. (1985) Isolation and partial characterization of a M, 32000 protein with inhibin activity from porcine follicular fluid. Proc. natn. Acad. Sci., USA 82, 7217-7221.

Mason, A.J., Hayflick, J.S., Ling, N., Esch, F., Ueno, N., Ying, S.Y., Guillemin, R., Niall, H. \& Seeburg, P.H. (1985) Complementary DNA sequence of ovarian follicular fluid inhibin shows precursor structure and homology with transforming growth factor beta. Nature, Lond. 318, 659-663.

McLachlan, R.I., Healy D.L., Robertson, D.M., Burger, H.G. \& de Kretser, D.M. (1987) Circulating immunoreactive inhibin in the luteal phase and early gestation in women undergoing ovulation induction. Fert. Steril. 48, 1001-1005. 
Merchenthaler, I., Culler, M.D., Petruz, P. \& NegroVilar, A. (1987) Immunocytochemical localization of inhibin in rat and human reproductive tissues. Molec. cell. Endocrinol. 54, 239-243.

Midgley, A.R., Jr (1979) Gonadotrophin binding to frozen sections of ovarian tissue. In Gonadotrophins, pp. 248-260. Eds C. G. Berlin \& H. M. Gandy. Wiley Interscience, New York.

Miyamoto, K., Hasegawa, Y., Fukuda, M., Nomura, M., Igarashi, M., Kangawa, K. \& Matsuo, H. (1985) Isolation of porcine follicular fluid of $32 \mathrm{~K}$ daltons. Biochem. Biophys. Res. Commun. 129, 396-403.

Moor, R.M., Hay, M.F., Dott, H.M. \& Cran, D.G. (1978) Macroscopic identification and steroidogenic function of atretic follicles in sheep. $J$. Endocr. 77, 309-318.

Rivier, J., Spiess, J., McClintock, R., Vaughan, J. \& Vale, W. (1985) Purification and partial characterization of inhibin from porcine follicular fluid. Biochem. Biophys. Res. Commun. 133, 120-127.

Robertson, D.M., Foulds, L.M., Leversha, L., Morgan, P.J., Hearn, M.T.W., Burger, H.G., Wettenhall, R.E.H. \& de Kretser, D.M. (1985) Isolation of inhibin from bovine follicular fluid. Biochem. Biophys. Res. Commun. 126, 220-226.

Robertson, D.M., de Vos, F.L., Foulds, L.M., McLachlan, R.I., Burger H.G., Morgan, F.J., Hearn, M.T. \& de Kretser, D.M. (1986) Isolation of a $31 \mathrm{kDa}$ form of inhibin from bovine follicular fluid. Molec. cell. Endocr. 3, 271-277.

Rodgers, R.J., Stuchbery, S.J. \& Findlay, J.K. (1989) Inhibin mRNA's in ovine and bovine ovarian follicles and corpora lutea throughout the estrous cycle and gestation. Molec. cell. Endocr. (In Press).

Tsonis, C.G., Quigg, H., Lee, V.W.K., Leversha, L., Trounson, A.O. \& Findlay, J.K. (1983) Inhibin in individual ovine follicles in relation to diameter and atresia. J. Reprod. Fert. 67, 83-90.

Tsonis, C.G., Hillier, S.G. \& Baird, D.T. (1987) Production of inhibin bioactivity by human granulosa lutein cells: stimulation by $\mathrm{LH}$ and testosterone in vitro. $J$. Endocr. 112, R11-R14.

Woodruff, T.K., D'Agnostino, J., Schwartz, N.B. \& Mayo, K.E. (1988) Dynamic changes in inhibin messenger RNAs in rat ovarian follicles during the reproductive cycle. Science, N.Y. 239, 1296-1299.

Zlotkin, T., Farkash, Y. \& Orly, J. (1986) Cell-specific expression of immunoreactive cholesterol sidechain cleavage cytochrome p-450 during follicular development in the rat ovary. Endocrinology 119, 2809-2820.

Received 25 October 1988 